\title{
RNA polymerase III transcription in cancer: the BRF2 connection
}

\author{
Stephanie Cabarcas $^{1}$ and Laura Schramm ${ }^{2 *}$
}

\begin{abstract}
RNA polymerase (pol) III transcription is responsible for the transcription of small, untranslated RNAs involved in fundamental metabolic processes such mRNA processing (U6 snRNA) and translation (tRNAs). RNA pol III transcription contributes to the regulation of the biosynthetic capacity of a cell and a direct link exists between cancer cell proliferation and deregulation of RNA pol III transcription. Accurate transcription by RNA pol III requires TFIIIB, a known target of regulation by oncogenes and tumor suppressors. There have been significant advances in our understanding of how TFIIIB-mediated transcription is deregulated in a variety of cancers. Recently, BRF2, a component of TFIIIB required for gene external RNA pol III transcription, was identified as an oncogene in squamous cell carcinomas of the lung through integrative genomic analysis. In this review, we focus on recent advances demonstrating how BRF2-TFIIIB mediated transcription is regulated by tumor suppressors and oncogenes. Additionally, we present novel data further confirming the role of BRF2 as an oncogene, extracted from the Oncomine database, a cancer microarray database containing datasets derived from patient samples, providing evidence that BRF2 has the potential to be used as a biomarker for patients at risk for metastasis. This data further supports the idea that BRF2 may serve as a potential therapeutic target in a variety of cancers.
\end{abstract}

\section{Introduction}

Cancer is a major health problem afflicting millions of Americans annually and despite tremendous research and treatment advances, is still the leading cause of death amongst men and women younger than age 85 years [1]. A dominant characteristic of many types of cancer cells is its ability to proliferate uncontrollably. RNA polymerase (pol) III contains the largest number of subunits (17 subunits) and is responsible for the transcription of small, less than 300 nucleotides, untranslated RNAs involved in fundamental metabolic processes, such as RNA processing (U6 snRNA) and translation (tRNAs), which contribute to cell proliferation [2]. Thus, deregulation of RNA pol III transcription can lead to aberrant production of critical RNAs contributing to uncontrolled cell growth, a hallmark trait of many types of cancer.

Like all eukaryotic polymerases, RNA pol III cannot recognize its target promoters directly and accurate

\footnotetext{
* Correspondence: schramml@stjohns.edu

${ }^{2}$ Department of Biological Sciences, St. John's University, Queens, New York 11439, USA

Full list of author information is available at the end of the article
}

initiation requires TFIIIB [2-4]. In higher eukaryotes, thus far, two forms of TFIIIB have been identified [2-4]. BRF1-TFIIIB required for transcription by gene internal RNA pol III promoters (tRNA) contains Bdp1, TBP and BRF1 (Figure 1). BRF2-TFIIIB required for transcription from RNA pol III gene external promoters contain Bdp1, TBP and BRF2 (Figure 1) [2]. Examples of genes transcribed by BRF2-TFIIIB include the human U6 snRNA gene involved in RNA splicing, the 7SK gene whose RNA product has been demonstrated to negatively regulate RNA Pol II transcription elongation by binding to the elongation factor P-TEFb, the RNase mitochondrial RNA processing (MRP) which participates in pre-rRNA processing, novel noncoding RNAs of unknown function (reviewed in $[2,5]$ ).

BRF2 (TFIIB-related factor 2) shares structural features with TFIIB and BRF1 (Figure 1B). TFIIB, BRF1 and BRF2 all contain $\mathrm{N}$-terminal zinc ribbon domains, core domains containing imperfect repeats; BRF1 and BRF2 have unrelated C-terminal extensions (Figure 1B) [2]. The C-terminus of BRF2 is required for association with TBP and SNAPc (small nuclear activating protein complex) on the U6 promoter [6].
C Biomed Central

다 2011 Cabarcas and Schramm; licensee BioMed Central Ltd. This is an Open Access article distributed under the terms of the Creative Commons Attribution License (http://creativecommons.org/licenses/by/2.0), which permits unrestricted use, distribution, and reproduction in any medium, provided the original work is properly cited. 


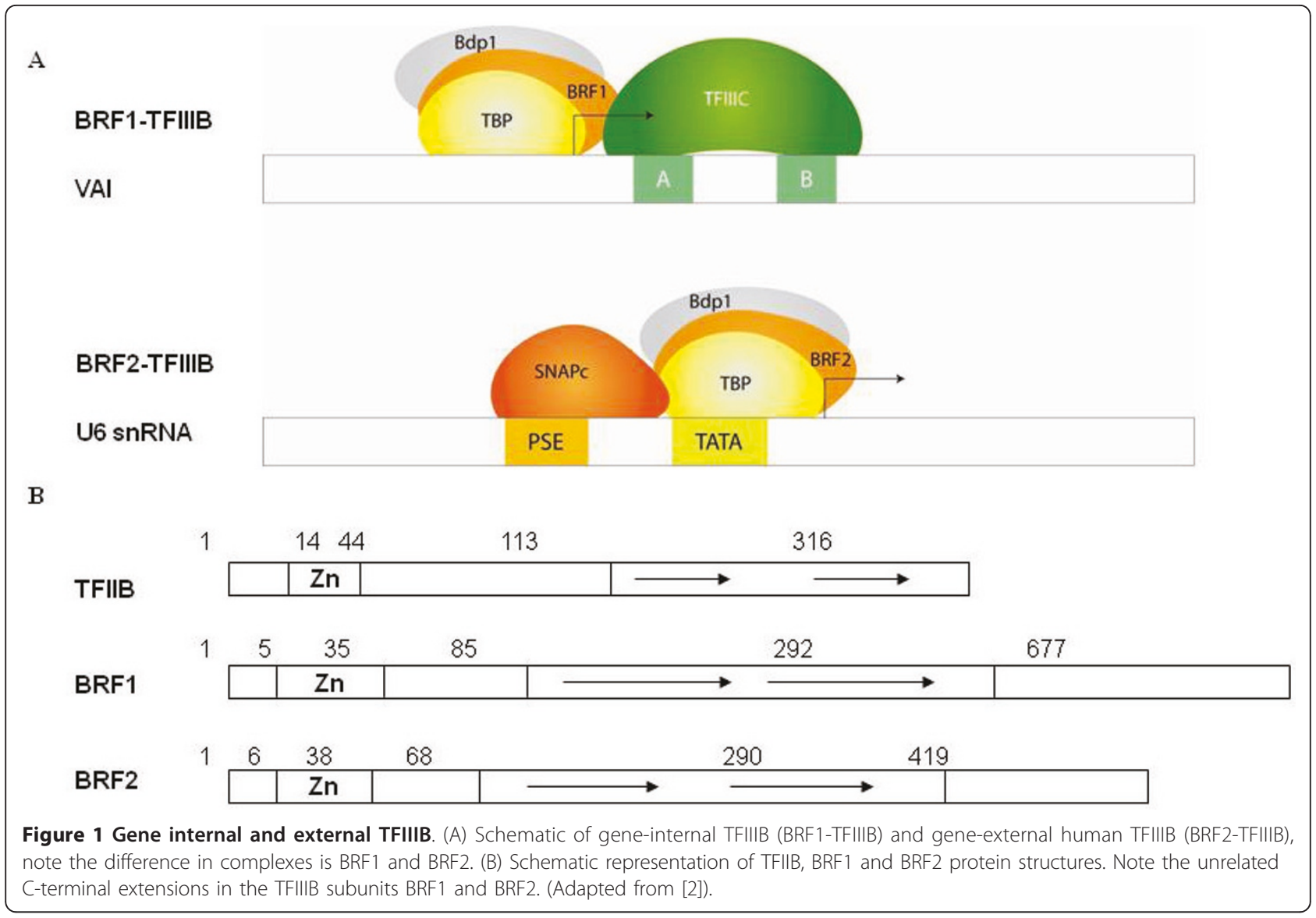

\section{RNA pol III and cancer}

Many different transformed cell types have been shown to have increased products of RNA pol III, when transformed by DNA tumor viruses, as well as chemical carcinogens [7-11] and their relevance has been validated in tumors of the breast, cervix, esophagus, lung, ovary, parotid, and tongue, but not in corresponding normal tissues tumors [12]. Specifically, RT-PCR analysis has demonstrated that tRNAs are overproduced consistently in human ovarian cancers [13]. Also, tRNA levels have been shown to be 10-fold higher in breast cancer cells than in normal cells [14]. These increases are not simply a consequence of rapid cell proliferation in cancer [15], but instead contribute to tumorigenesis, as it has been demonstrated that overexpression of tRNAi ${ }^{\mathrm{Met}}$ induces proliferation and immortalization of fibroblasts [16].

Activation of TFIIIB activity has been noted in a variety of cancers types. Increased TBP expression has been observed in a clinically significant number of human colon cancers [17]. Also, overexpression of BRF1 has also been shown to transform mouse embryo fibroblasts [16]. Bdp1 is overexpressed in cells transformed by papovaviruses [11], but changes in expression levels in specific human cancer types have not been determined.
Amplification of BRF2 has been noted in breast cancer $[18,19]$ and more recently a human bladder cancer cell line [20]. Recently, Lockwood et al. demonstrated that genetic activation of BRF2 represents a unique mechanism of squamous cell carcinoma tumorigenesis, also providing the first clinical evidence implicating BRF2 as a novel lineage-specific oncogene in lung squamous cell carcinoma [20]. This review will focus on BRF2-TFIIIB activity in cancer.

\section{Regulation of BRF2-TFIIIB activity by oncogenes and tumor suppressors}

RNA pol III transcription is tightly regulated during the cell cycle to ensure normal cellular growth [21]. Cellular levels of RNA pol III are specifically increased in tissues isolated from mice with myeloma compared to tumorfree mice [22], directly linking RNA pol III activity and cancer. Recently, it was demonstrated that BRF1 and TBP are capable of driving oncogenic transformation $[16,23]$. These observations demonstrate that elevation of RNA pol III transcription contributes to oncogenesis. TFIIIB activity is strictly regulated by Maf1 [24-27], chemopreventative agents [28], and oncogenes and tumor suppressors which are discussed below. 


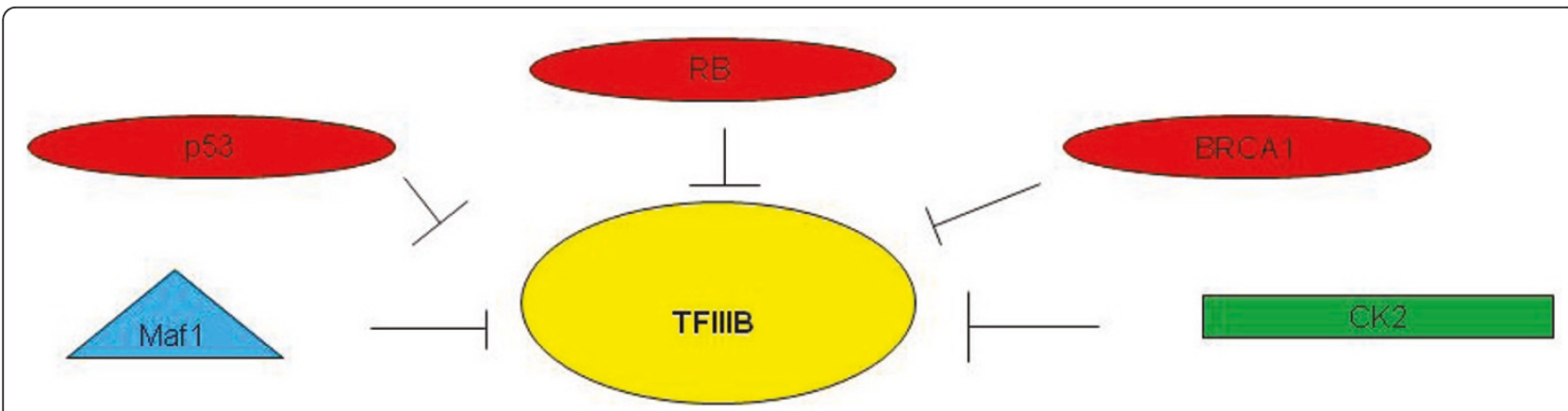

Figure 2 BRF2-TFIIIB is a target of regulation by tumor suppressors and oncogenic products. Depiction of tumor suppressor and oncogenic products involved in the regulation of BRF2-TFIIIB. The tumor suppressors, p53, RB and BRCA1 are depicted as red circles. The oncogenic kinase CK2 is depicted by a green box and functions in regulating BRF2-TFIIIB. The stress related protein Maf1 is depicted by a triangle and functions in inhibiting BRF2-TFIIIB.

CK2 (casein kinase 2) is a ubiquitous and conserved protein kinase with growth-promoting and oncogenic properties. CK2 is abnormally active in a variety of human cancers (Figure 2) [29]. It has been demonstrated that CK2 interacts stably with TFIIIB; BRF1 is phosphorylated in cells and CK2 inhibitors can decrease this phosphorylation, thereby promoting transcription complex assembly [29].

TFIIIB activity is targeted by tumor suppressors [30-36] such as ARF [37], RB (Retinoblastoma protein) [30,38], p53 [39-43] and BRCA1 (breast cancer susceptibility gene 1) [44].

RB controls cell growth by preventing cell cycle entry in the absence of appropriate mitogenic signals and inactivation is associated with a variety of human cancers [45]. RB regulates RNA pol III transcription by disrupting interactions between TFIIIB and RNA pol III [38,46-49] RB-mediated repression of U6 transcription can be restored by recombinant SNAPc and TBP [46].

p53 is activated in response to cellular stress, inducing cell cycle arrest or apoptosis, and its inactivation is considered a critical step in carcinogenesis [50]. p53 represses not only Alu and U6 transcription, but also tRNA, 5S rRNA, VAI, B2 and EBER (Epstein-Barr virus) transcription, establishing p53 as a general repressor of RNA pol III transcription [39]. p53 regulates U6 transcription through interaction with the BRF2-TFIIIB subunit TBP [41] and SNAPc [51].

BRCA1 plays a role in DNA repair, cell cycle regulation, apoptosis, genome integrity and ubiquitination $[52,53]$. Recently, BRCA1 has been characterized as a general repressor of RNA pol III transcription [44]. BRF2 overexpression alleviates BRCA1 mediated repression of U6 transcription [44], suggesting that regulation of U6 transcription by BRCA1 occurs, in part, through BRF2. However, it is currently unclear whether the observed inhibition of RNA pol III transcription is a result of direct or indirect interactions between BRCA1 and BRF2, or BRCA1 and TFIIIB in general.

\section{BRF2, a general oncogene?}

It is established that RNA pol III is often deregulated in cancers [33-35] and specific elevation of RNA pol III transcripts and RNA pol III transcription factors such as U6 snRNA and BRF2 is a feature of both transformed cells and cancers [54]. Recently, Lockwood et al identified BRF2 as a novel oncogene in lung squamous cell carcinoma demonstrating that overexpression of BRF2 can drive expression of RNA pol III transcripts contributing to squamous cell carcinoma tumorigenesis [20]. However, it cannot currently be ruled out that TFIIIB, particularly the BRF2 subunit, could bind and potentially titrate tumor suppressors, thus alleviating some key mechanisms normally keeping TFIIIB activity in check, contributing to oncogenesis. Additionally, no Brf2dependent pol III transcript has yet been shown to have transforming activity.

RNA pol III is a fundamental determinant of the capacity of a cell to grow and the identification of BRF2 as an oncogene further demonstrates the importance of proper regulation of RNA pol III transcription. Hence, we queried the Oncomine database to systematically assess gene expression levels of BRF2 in a variety of carcinomas. Oncomine is a bioinformatics initiative which collects, standardizes, analyzes, and delivers cancer transcriptome data to the biomedical research community [55]. Rhodes et al. analysis of cancer transcriptome data has identified the genes, pathways, and networks deregulated across 18,000 cancer gene expression microarrays spanning 35 cancer types (for a comprehensive overview of the Oncomine database refer to [55]). Differential expression analysis is an important feature of the Oncomine resource. A unique feature of the Oncomine database is Oncomine automatically computes differential 


\section{Disease Summary for BRF2}

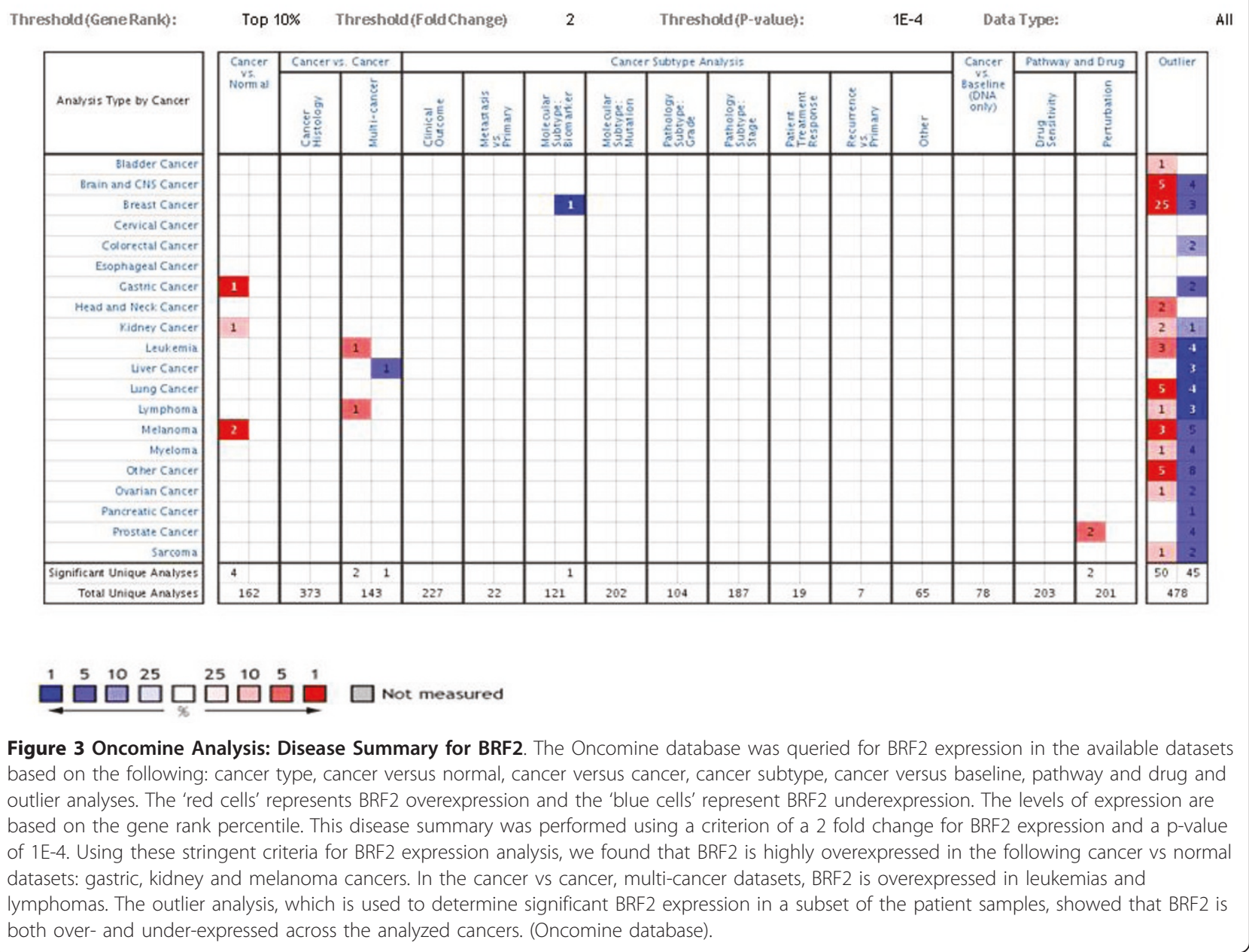

expression profiles for cancer types and subtypes allowing for simple query for individual gene expression.

Thus, using the Oncomine database, we performed a disease summary for BRF2 (Figure 3) to determine if BRF2 overexpression was significant in various carcinomas. Based on this analysis, we determined that in studies comparing cancer versus normal tissue, BRF2 is highly overexpressed in datasets focused on gastric, kidney and melanoma cancers. Please note that sample number for each data set used in our BRF2 analysis is noted, and data sets are named for author whose data set has been analyzed. In Figure 3, overexpression represented by 'red cells' and under expression represented by 'blue cells' is determined based on the gene rank percentile. The outlier analysis, as demonstrated in Figure 3, suggests that there are 50 analyses which have a significant increase in BRF2 expression and 45 analyses which have a significant decrease in BRF2 expression. The outlier analyses represents a small subpopulation of samples within the datasets, hence, they do not reflect the majority of samples. We speculate that out of the 478 unique analyses, the 45 analyses which have a significant decrease of BRF2 expression demonstrates that BRF2 overexpression may not be universal to all cancer patients. The Oncomine database is a compilation of gene expression studies performed from clinically-based analyses performed on patient samples. The 4 analyses which are significant out of 162 that are significant include gastric, kidney and melanoma cancer datasets (Figure 3). This criterion for this specific BRF2 disease summary performed was stringent as we required a p-value of $1 \mathrm{E}-4$ and a fold-change of 2 for BRF2 gene expression compared to the controls. Hence, we believe that due to the stringency of our criterion, only 4 analyses showed a significant increase in BRF2 expression. 


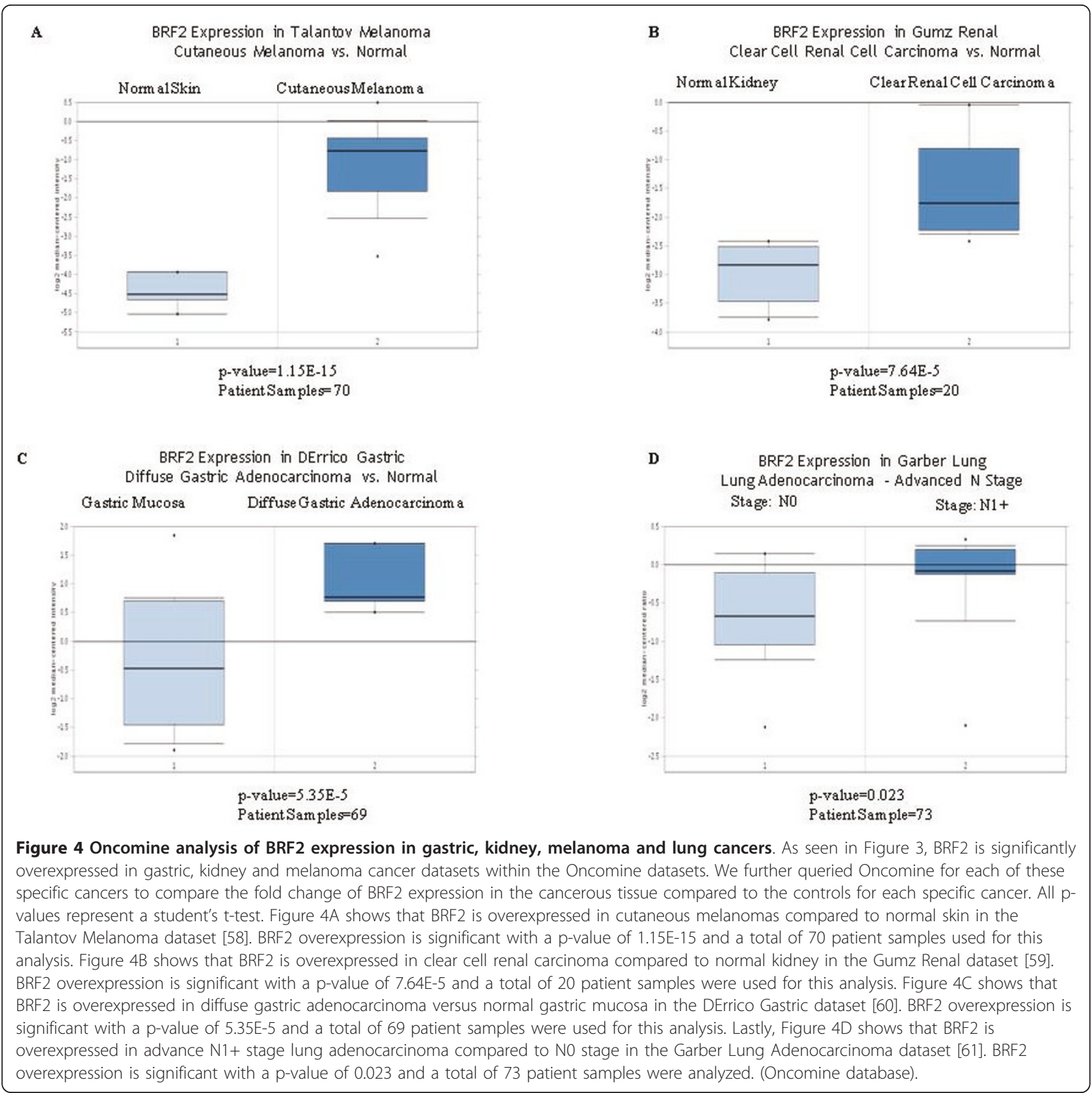

We further queried the analyses which had a significant increase in BRF2 expression and as demonstrated in Figure 4A, the Talantov Melanoma dataset, comprised of 70 patient samples shows a statistically significant overexpression of BRF2 mRNA, p-value $=1.15 \mathrm{E}$ 15 , in cutaneous melanoma compared to normal skin. Figure $4 \mathrm{~B}$ shows a statistically significant overexpression of BRF2 mRNA, p-value $=7.64 \mathrm{E}-5$, in clear renal cell carcinoma compared to normal kidney in the Gumz Renal dataset, comprised of 20 patient samples. Lastly, Figure $4 \mathrm{C}$ shows a statistically significant overexpression of BRF2 mRNA, p-value $=5.35 \mathrm{E}-5$, in the DErrico Gastric diffuse gastric adenocarcinoma compared to gastric mucosa dataset, comprised of 69 patient samples. Additionally, Lockwood et al have recently identified BRF2 as an oncogene in lung squamous cell carcinoma [20]. To determine if there was a correlation with BRF2 overexpression and lung carcinoma, we analyzed the Garber Lung dataset, comprised of 73 patient samples, Figure 4D. The data retrieved from the Garber Lung study shows a correlation between BRF2 overexpression and an advanced $\mathrm{N}$ stage, N1, in lung carcinoma samples. 

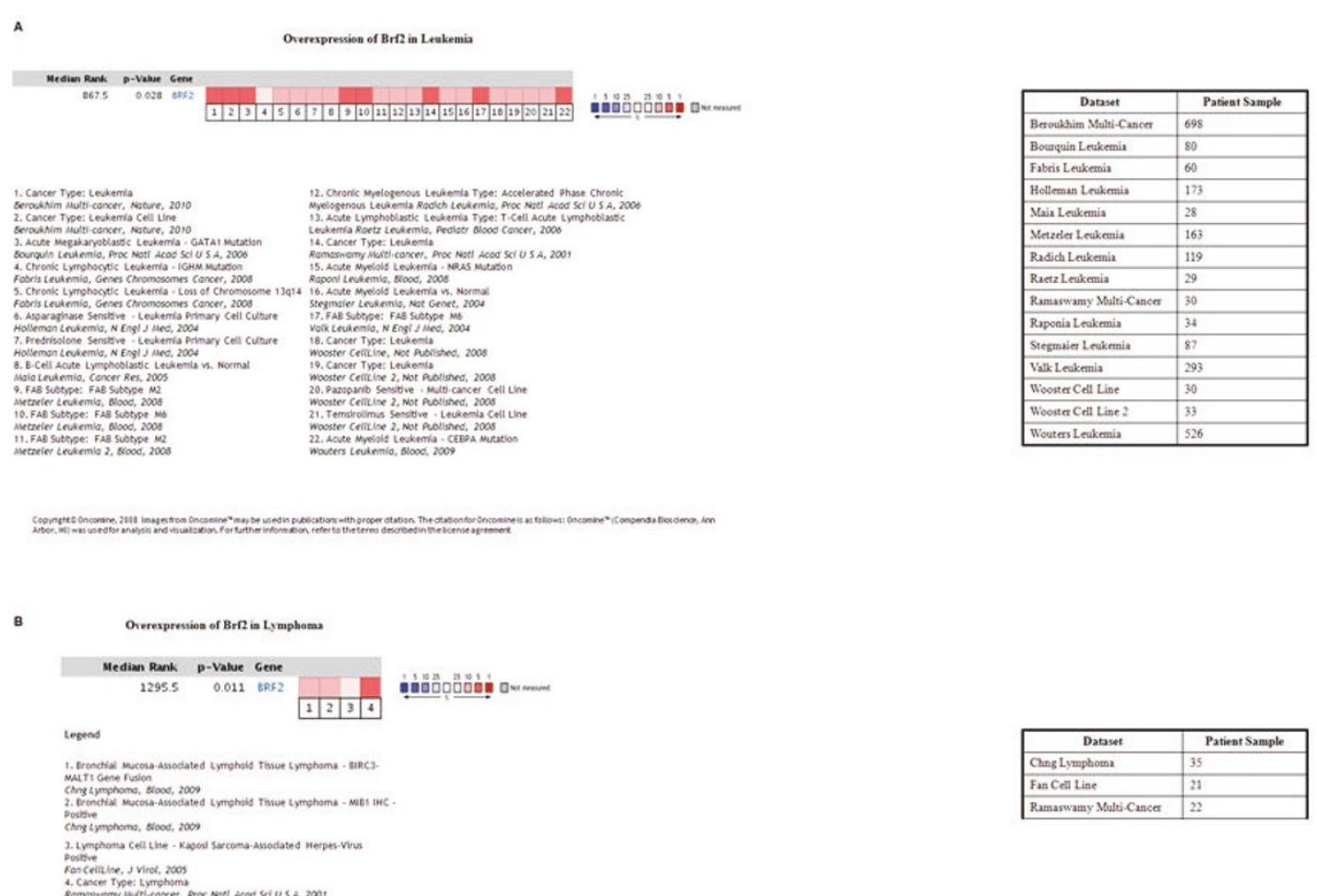

Figure 5 Oncomine analysis of BRF2 expression in leukemia and lymphoma. As demonstrated in Figure 3, BRF2 is overexpressed in both leukemia and lymphoma, cancer vs cancer datasets. We further queried the Oncomine database to analyze BRF2 expression in both leukemia and lymphoma. Figure 5A represents an analysis performed across 22 leukemia analyses found within Oncomine. The p-value, 0.028, represents a student's t-test measuring BRF2 overexpression in cancerous tissues, and the red represents significant overexpression. This analysis shows that BRF2 is significantly overexpressed across leukemia. The table states the datasets analyzed and the number of patient samples used in each study. Figure 5B represents an analysis performed across 4 lymphoma analyses found within Oncomine. The p-value, 0.011 , represents a student's t-test measuring BRF2 overexpression in cancerous tissue and the red represents significant overexpression. This analysis shows that BRF2 is significantly overexpressed across lymphoma. The table states the datasets used for analysis and the number of patient samples used in each study. (Oncomine database).

All statistical values relative to these analyses were calculated as previously described [55].

Further query of the information presented in the BRF2 disease summary demonstrated that in analyses comparing multi-cancers, "cancer versus cancer", BRF2 is overexpressed in both leukemia and lymphoma as well. In the case of BRF2 expression in leukemia, we searched various leukemia datasets and found that across 22 analyses, BRF2 was significantly overexpressed, Figure 5A, p-value $=0.028$. In the case of BRF2 expression in lymphoma, we found that across 4 analyses, BRF2 was significantly overexpressed, Figure $5 \mathrm{~B}$, p-value $=0.011$.

Interestingly, analysis of the BRF2 disease summary shows that BRF2 is highly expressed on the basis of outlier gene expression using a method called COPA (cancer outlier profile analysis). COPA was previously described and utilized to identify oncogenic chromosomal aberrations such as the TMPRSS2:ETS fusion gene in prostate cancer by Tomlins et al [56]. Based on the BRF2 disease summary, we focused on breast carcinoma as this was most significant. Analysis of the $95 \%$ outlier across 17 breast carcinoma analyses (Figure 6) shows that BRF2 is highly overexpressed. This demonstrates that in $5 \%$ of the samples analyzed in these specific studies, BRF2 overexpression is significant in a small subpopulation of samples.

Lastly, we investigated if there was a correlation between BRF2 overexpression and clinical outcome. Using breast carcinoma studies, we performed a metaanalysis across 10 different breast carcinoma datasets studying recurrence, metastasis and death, Figure 7A. We determined that BRF2 overexpression did indeed correlate with clinical outcome. Figure $7 \mathrm{~B}$ represents one dataset analyzed in Figure $7 \mathrm{~A}$, the vandeVijver breast carcinoma study, and shows that BRF2 overexpression is highly significant in patients presenting with metastasis at year $1, \mathrm{p}$-value $=0.034$, and at year 5 , 


\section{COPAAnalysis of Brf2 Across 17 Analyses of Breast Carcinoma}

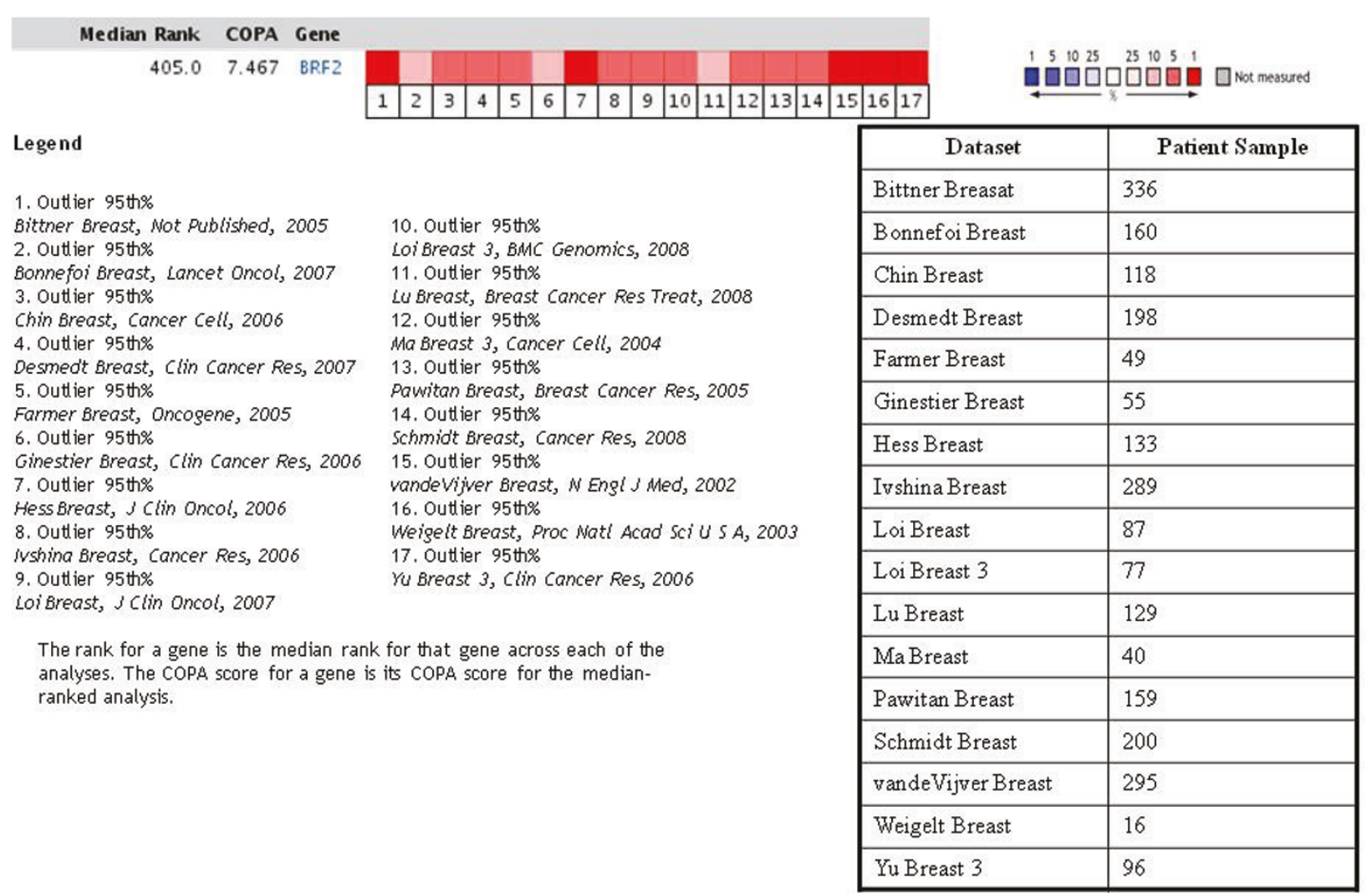

Figure 6 Oncomine analysis of BRF2 expression in breast carcinoma using COPA. As seen in Figure 3, BRF2 was overexpressed in a total of 50 analyses using an outlier analysis. COPA (cancer outlier profile analysis) analyzes a small subpopulation of samples which represent outliers within the datasets for significant expression and does not represent the majority of samples. We investigated BRF2 expression in several breast carcinoma studies based on the high number of analyses BRF2 was overexpressed in using COPA (Figure 3). Based on the COPA method, BRF2 is highly overexpressed across 17 breast carcinoma analyses in a subset of the patient samples used for each respective analysis. The red represents significant overexpression. The datasets used for this analysis and the number of patient samples used in each individual study are shown as well. (Oncomine database).

$\mathrm{p}$-value $=0.006$. This data set is extremely significant at it shows promise for the potential use of BRF2 as a potential biomarker for patients at risk for metastasis and may serve as a potential therapeutic target.

Recently, RNA pol III transcription has been the focus of a Phase I and pharmacokinetic study. HammondThelin et al. studied the effects of a novel nucleoside analog inhibitor (TAS-106) of RNA pol I, II and III, in patients with advanced solid malignancies [57]. Previously, TAS-106 has demonstrated antitumor activity in various human cancer models including leukemic, lung, colorectal, stomach, pancreatic, and gastric cancers [57]. The principal objectives of the study were to determine the maximum tolerated dose in patients, characterize the toxicities associated with TAS-106 administration, determine the pharmacokinetics of TAS-106 and study if there was any indication of antitumor activity in patients [57]. Although this study is in its infancy, it's representative of the potential use of RNA pol III inhibitors as a means of pharmacological target for the treatment of cancers.

\section{Conclusions}

By elucidating the mechanism(s) by which RNA pol III transcription is both regulated and deregulated, it will be possible to further understand the mechanism(s) by which aberrant activity of the general transcription machinery contributes to cancer development. Deregulation of RNA pol III transcription in cancers coupled with the observation that TFIIIB, specifically BRF2-TFIIIB, is commonly a target of deregulation in a variety of cancers demonstrates that RNA pol III transcription is indeed a key player in tumorigenesis and could serve as a novel target in the development of pharmacological agents. 


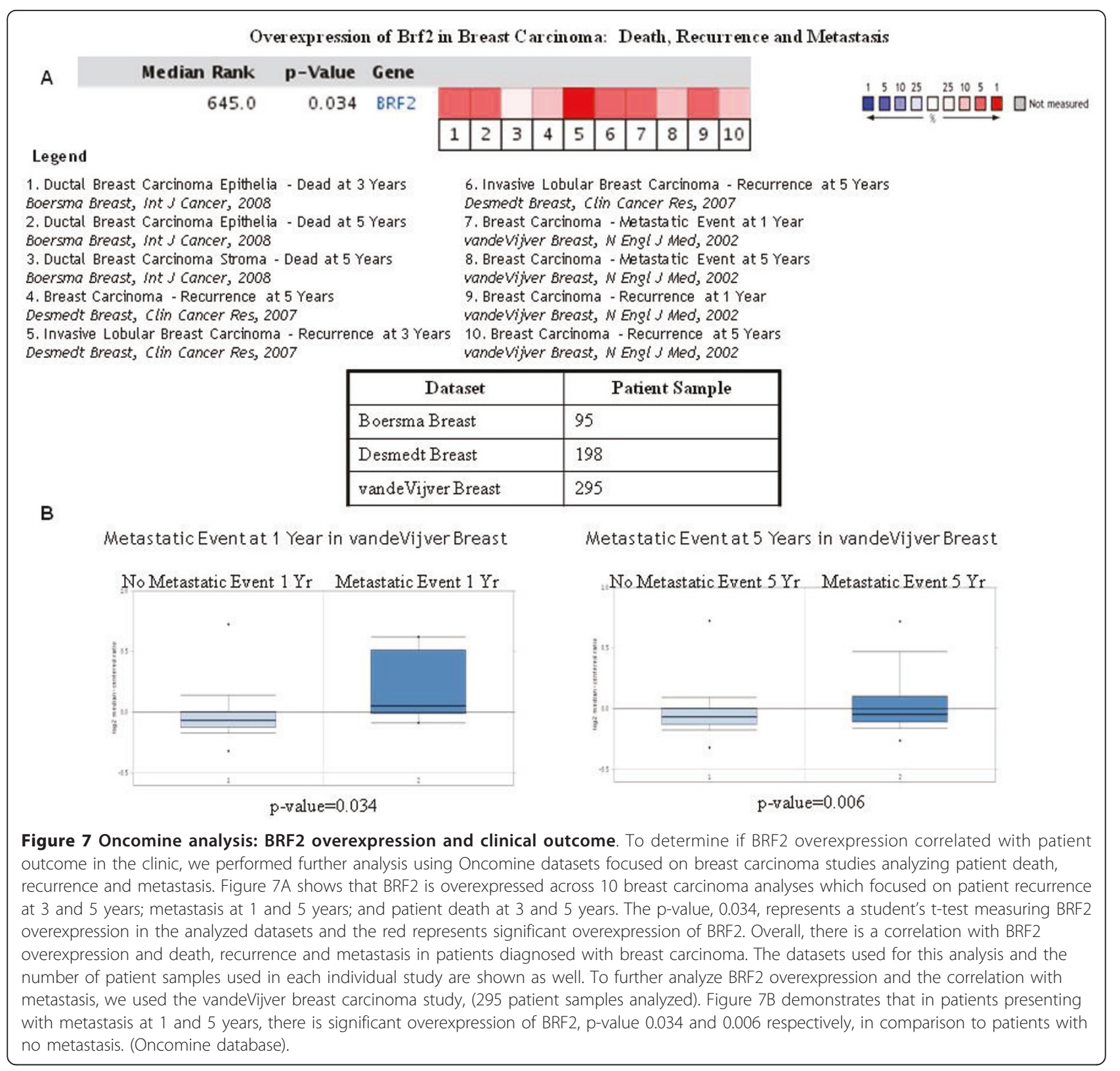

\section{Acknowledgements}

This work was supported in part by NIH grant 1R15CA133842-01A1 (LS). The authors wish to apologize, due to space restrictions, that not all TFIIIB studies could be mentioned. We thank Dr. Joby Jacob for his assistance with figure preparation.

\section{Author details}

'National Cancer Institute, Laboratory of Cancer Prevention, Cancer Stem Cell Section, 1050 Boyles Street, Building 560, Room 21-81, Frederick, MD 21702, USA. ${ }^{2}$ Department of Biological Sciences, St. John's University, Queens, New York 11439, USA.

\section{Authors' contributions}

SC reviewed the literature, wrote and drafted the manuscript; LS corrected and finalized the manuscript. All authors read and approved the final version.

\section{Competing interests}

The authors declare that they have no competing interests.

Received: 13 December 2010 Accepted: 25 April 2011 Published: 25 April 2011

\section{References}

1. Jemal A, Siegel R, Ward E, Hao Y, Xu J, Thun MJ: Cancer statistics, 2009. CA Cancer J Clin 2009, 59(4):225-49.

2. Schramm L, Hernandez N: Recruitment of RNA polymerase III to its target promoters. Genes Dev 2002, 16(20):2593-620.

3. Huang Y, Maraia RJ: Comparison of the RNA polymerase III transcription machinery in Schizosaccharomyces pombe, Saccharomyces cerevisiae and human. Nucleic Acids Res 2001, 29(13):2675-90.

4. Geiduschek EP, Kassavetis GA: The RNA polymerase III transcription apparatus. J Mol Biol 2001, 310(1):1-26. 
5. Dieci G, Fiorino G, Castelnuovo M, Teichmann M, Pagano A: The expanding RNA polymerase III transcriptome. Trends Genet 2007, 23(12):614-22.

6. Saxena A, Ma B, Schramm L, Hernandez N: Structure-function analysis of the human TFIIB-related factor II protein reveals an essential role for the C-terminal domain in RNA polymerase III transcription. Mol Cell Biol 2005, 25(21):9406-18.

7. Wang $\mathrm{HD}$, Yuh $\mathrm{CH}$, Dang $\mathrm{CV}$, Johnson $\mathrm{DL}$ : The hepatitis $\mathrm{B}$ virus $\mathrm{X}$ protein increases the cellular level of TATA-binding protein, which mediates transactivation of RNA polymerase III genes. Mol Cell Biol 1995, 15(12):6720-8

8. White RJ, Stott D, Rigby PW: Regulation of RNA polymerase III transcription in response to Simian virus 40 transformation. Embo J 1990 9(11):3713-21.

9. Gottesfeld JM, Johnson DL, Nyborg JK: Transcriptional activation of RNA polymerase III-dependent genes by the human T-cell leukemia virus type 1 tax protein. Mol Cell Biol 1996, 16(4):1777-85.

10. Larminie CG, Sutcliffe JE, Tosh K, Winter AG, Felton-Edkins ZA, White RJ: Activation of RNA polymerase III transcription in cells transformed by simian virus 40. Mol Cell Biol 1999, 19(7):4927-34.

11. Felton-Edkins ZA, White RJ: Multiple mechanisms contribute to the activation of RNA polymerase III transcription in cells transformed by papovaviruses. J Biol Chem 2002, 277(50):48182-91.

12. Chen W, Bocker W, Brosius J, Tiedge H: Expression of neural BC200 RNA in human tumours. J Pathol 1997, 183(3):345-51.

13. Winter AG, Sourvinos G, Allison SJ, Tosh K, Scott PH, Spandidos DA, White RJ: RNA polymerase III transcription factor TFIIIC2 is overexpressed in ovarian tumors. Proc Natl Acad Sci USA 2000, 97(23):12619-24.

14. Pavon-Eternod M, Gomes S, Geslain R, Dai Q, Rosner MR, Pan T: tRNA overexpression in breast cancer and functional consequences. Nucleic Acids Res 2009, 37(21):7268-80.

15. Marshall L, White RJ: Non-coding RNA production by RNA polymerase III is implicated in cancer. Nat Rev Cancer 2008, 8(12):911-4.

16. Marshall L, Kenneth NS, White RJ: Elevated tRNA(iMet) synthesis can drive cell proliferation and oncogenic transformation. Cell 2008, 133(1):78-89.

17. Johnson SA, Dubeau L, Kawalek M, Dervan A, Schonthal AH, Dang CV, Johnson DL: Increased expression of TATA-binding protein, the central transcription factor, can contribute to oncogenesis. Mol Cell Biol 2003, 23(9):3043-51.

18. Melchor L, Garcia MJ, Honrado E, Pole JC, Alvarez S, Edwards PA, Caldas C, Brenton JD, Benitez J: Genomic analysis of the 8p11-12 amplicon in familial breast cancer. Int J Cancer 2007, 120(3):714-7.

19. Garcia MJ, Pole JC, Chin SF, Teschendorff A, Naderi A, Ozdag H, Vias M, Kranjac T, Subkhankulova T, Paish C, Ellis I, Brenton JD, Edwards PA, Caldas C: A 1 Mb minimal amplicon at 8p11-12 in breast cancer identifies new candidate oncogenes. Oncogene 2005, 24(33):5235-45.

20. Lockwood WW, Chari R, Coe BP, Thu KL, Garnis C, Malloff CA, Campbell J, Williams AC, Hwang D, Zhu CQ, Buys TP, Yee J, English JC, Macaulay C, Tsao MS, Gazdar AF, Minna JD, Lam S, Lam WL: Integrative Genomic Analyses Identify BRF2 as a Novel Lineage-Specific Oncogene in Lung Squamous Cell Carcinoma. PLoS Med 2010, 7(7):e1000315.

21. Scott PH, Cairns CA, Sutcliffe JE, Alzuherri HM, McLees A, Winter AG, White RJ: Regulation of RNA polymerase III transcription during cell cycle entry. J Biol Chem 2001, 276(2):1005-14

22. Schwartz LB, Sklar VE, Jaehning JA, Weinmann R, Roeder RG: Isolation and partial characterization of the multiple forms of deoxyribonucleic aciddependent ribonucleic acid polymerase in the mouse myeloma, MOPC 315. J Biol Chem 1974, 249(18):5889-97.

23. Johnson SA, Dubeau L, Johnson DL: Enhanced RNA polymerase IIIdependent transcription is required for oncogenic transformation. J Biol Chem 2008, 283(28):19184-91.

24. Johnson SS, Zhang C, Fromm J, Willis IM, Johnson DL: Mammalian Maf1 is a negative regulator of transcription by all three nuclear RNA polymerases. Mol Cell 2007, 26(3):367-79.

25. Reina JH, Azzouz TN, Hernandez N: Maf1, a New Player in the Regulation of Human RNA Polymerase III Transcription. PLOS ONE 2006, 1:e134.

26. Rollins J, Veras I, Cabarcas S, Willis I, Schramm L: Human Maf1 negatively regulates RNA polymerase III transcription via the TFIIB family members Brf1 and Brf2. Int J Biol Sci 2007, 3(5):292-302.

27. Goodfellow SJ, Graham EL, Kantidakis T, Marshall L, Coppins BA, OficjalskaPham D, Gerard M, Lefebvre O, White RJ: Regulation of RNA Polymerase III Transcription by Maf1 in Mammalian Cells. J Mol Biol 2008.
28. Jacob J, Cabarcas S, Veras I, Zaveri N, Schramm L: The green tea component EGCG inhibits RNA polymerase III transcription. Biochem Biophys Res Commun 2007, 360(4):778-83.

29. Johnston IM, Allison SJ, Morton JP, Schramm L, Scott PH, White RJ: CK2 forms a stable complex with TFIIIB and activates RNA polymerase III transcription in human cells. Mol Cell Biol 2002, 22(11):3757-68.

30. Felton-Edkins ZA, Kenneth NS, Brown TR, Daly NL, Gomez-Roman N Grandori C, Eisenman RN, White RJ: Direct regulation of RNA polymerase III transcription by RB, p53 and c-Myc. Cell Cycle 2003, 2(3):181-4.

31. Marshall L, White RJ: Non-coding RNA production by RNA polymerase III is implicated in cancer. Nat Rev Cancer 2008.

32. Mauger $E$, Scott PH: Mitogenic stimulation of transcription by RNA polymerase III. Biochem Soc Trans 2004, 32(Pt 6):976-7.

33. White RJ: RNA polymerase III transcription-a battleground for tumour suppressors and oncogenes. Eur J Cancer 2004, 40(1):21-7.

34. White RJ: RNA polymerase III transcription and cancer. Oncogene 2004, 23(18):3208-16.

35. White RJ: RNA polymerases I and III, growth control and cancer. Nat Rev Mol Cell Biol 2005, 6(1):69-78.

36. White RJ: RNA polymerases I and III, non-coding RNAs and cancer. Trends Genet 2008.

37. Morton JP, Kantidakis T, White RJ: RNA polymerase III transcription is repressed in response to the tumour suppressor ARF. Nucleic Acids Res 2007, 35(9):3046-52.

38. Chu WM, Wang Z, Roeder RG, Schmid CW: RNA polymerase III transcription repressed by $\mathrm{Rb}$ through its interactions with TFIIIB and TFIIIC2. J Biol Chem 1997, 272(23):14755-61.

39. Cairns CA, White RJ: p53 is a general repressor of RNA polymerase III transcription. Embo J 1998, 17(11):3112-23.

40. Chesnokov I, Chu WM, Botchan MR, Schmid CW: p53 inhibits RNA polymerase III-directed transcription in a promoter-dependent manner. Mol Cell Biol 1996, 16(12):7084-8.

41. Crighton D, Woiwode A, Zhang C, Mandavia N, Morton JP, Warnock LJ, Milner J, White RJ, Johnson DL: p53 represses RNA polymerase III transcription by targeting TBP and inhibiting promoter occupancy by TFIIIB. Embo J 2003, 22(11):2810-20.

42. Stein T, Crighton D, Boyle JM, Varley JM, White RJ: RNA polymerase II transcription can be derepressed by oncogenes or mutations that compromise p53 function in tumours and Li-Fraumeni syndrome. Oncogene 2002, 21(19):2961-70.

43. Stein T, Crighton D, Warnock L, Milner J, White RJ: Several regions of p53 are involved in repression of RNA polymerase III transcription. Oncogene 2002, 21(36):5540-7.

44. Veras I, Rosen EM, Schramm L: Inhibition of RNA Polymerase III Transcription by BRCA1. Journal of Molecular Biology 2009, 387(3):523-531.

45. Burkhart DL, Sage J: Cellular mechanisms of tumour suppression by the retinoblastoma gene. Nat Rev Cancer 2008, 8(9):671-82.

46. Hirsch HA, Gu L, Henry RW: The retinoblastoma tumor suppressor protein targets distinct general transcription factors to regulate RNA polymerase III gene expression. Mol Cell Biol 2000, 20(24):9182-91.

47. Larminie CG, Cairns CA, Mital R, Martin K, Kouzarides T, Jackson SP, White RJ: Mechanistic analysis of RNA polymerase III regulation by the retinoblastoma protein. Embo J 1997, 16(8):2061-71.

48. Sutcliffe JE, Brown TR, Allison SJ, Scott PH, White RJ: Retinoblastoma protein disrupts interactions required for RNA polymerase III transcription. Mol Cell Biol 2000, 20(24):9192-202.

49. White RJ, Trouche D, Martin K, Jackson SP, Kouzarides T: Repression of RNA polymerase III transcription by the retinoblastoma protein. Nature 1996, 382(6586):88-90.

50. Kruse JP, Gu W: Modes of p53 regulation. Cell 2009, 137(4):609-22.

51. Gridasova AA, Henry RW: The p53 Tumor Suppressor Protein Represses Human snRNA Gene Transcription by RNA Polymerases II and III Independently of Sequence-Specific DNA Binding. Mol Cell Biol 2005, 25(8):3247-3260

52. Billack B, Monteiro AN: BRCA1 in breast and ovarian cancer predisposition. Cancer Lett 2005, 227(1):1-7.

53. Deng CX: BRCA1: cell cycle checkpoint, genetic instability, DNA damage response and cancer evolution. Nucleic Acids Res 2006, 34(5):1416-26.

54. Cabarcas S, Jacob J, Veras I, Schramm L: Differential expression of the TFIIIB subunits Brf1 and Brf2 in cancer cells. BMC Mol Biol 2008, 9:74. 
55. Rhodes DR, Kalyana-Sundaram S, Mahavisno V, Varambally R, Yu J, Briggs BB, Barrette TR, Anstet MJ, Kincead-Beal C, Kulkarni P, Varambally S, Ghosh D, Chinnaiyan AM: Oncomine 3.0: genes, pathways, and networks in a collection of 18,000 cancer gene expression profiles. Neoplasia 2007, 9(2):166-80.

56. Tomlinson GE, Chen $T$, Stastny VA, Virmani AK, Spillman MA, Tonk V, Blum JL, Schneider NR, Wistuba II, Shay JW, Minna JD, Gazdar AF: Characterization of a breast cancer cell line derived from a germ-line BRCA1 mutation carrier. Cancer Res 1998, 58(15):3237-42.

57. Hammond-Thelin LA, Thomas MB, Iwasaki M, Abbruzzese JL, Lassere $Y$, Meyers CA, Hoff P, de Bono J, Norris J, Matsushita H, Mita A, Rowinsky EK: Phase I and pharmacokinetic study of 3'-C-ethynylcytidine (TAS-106), an inhibitor of RNA polymerase I, II and III, in patients with advanced solid malignancies. Invest New Drugs 2010.

58. Talantov D, Mazumder A, Yu JX, Briggs T, Jiang Y, Backus J, Atkins D, Wang Y: Novel genes associated with malignant melanoma but not benign melanocytic lesions. Clin Cancer Res 2005, 11(20):7234-42.

59. Gumz ML, Zou H, Kreinest PA, Childs AC, Belmonte LS, LeGrand SN, Wu KJ, Luxon BA, Sinha M, Parker AS, Sun LZ, Ahlquist DA, Wood CG, Copland JA: Secreted frizzled-related protein 1 loss contributes to tumor phenotype of clear cell renal cell carcinoma. Clin Cancer Res 2007, 13(16):4740-9.

60. D'Errico M, de Rinaldis E, Blasi MF, Viti V, Falchetti M, Calcagnile A, Sera F, Saieva C, Ottini L, Palli D, Palombo F, Giuliani A, Dogliotti E: Genome-wide expression profile of sporadic gastric cancers with microsatellite instability. Eur J Cancer 2009, 45(3):461-9.

61. Kickhoefer VA, Searles RP, Kedersha NL, Garber ME, Johnson DL, Rome LH: Vault ribonucleoprotein particles from rat and bullfrog contain a related small RNA that is transcribed by RNA polymerase III. J Biol Chem 1993, 268(11):7868-73.

doi:10.1186/1476-4598-10-47

Cite this article as: Cabarcas and Schramm: RNA polymerase III transcription in cancer: the BRF2 connection. Molecular Cancer 2011 10:47.

\section{Submit your next manuscript to BioMed Central and take full advantage of:}

- Convenient online submission

- Thorough peer review

- No space constraints or color figure charges

- Immediate publication on acceptance

- Inclusion in PubMed, CAS, Scopus and Google Scholar

- Research which is freely available for redistribution

Submit your manuscript at www.biomedcentral.com/submit 